\title{
Urinary nitrogen concentration from dairy heifers grazing kale supplemented with either plantain or perennial ryegrass baleage in winter
}

\author{
H.G. JUDSON ${ }^{1}$ and G.R. EDWARDS ${ }^{2}$ \\ ${ }^{1}$ Agricom, P.O Box 3761, Christchurch, New Zealand \\ ${ }^{2}$ Agriculture and Life Sciences Faculty, Lincoln University, P.O Box 84, Lincoln University, New Zealand \\ gjudson@agricom.co.nz
}

\begin{abstract}
The effect of feeding two different supplements (perennial ryegrass or plantain baleage) on urinary nitrogen $(\mathrm{N})$ excretion from dairy heifers (8 months old, $180 \mathrm{~kg}$ liveweight (LW)) grazing kale was examined in two successive winters. Heifers ( $\mathrm{n}=90$ and 80 in Years 1 and 2 , respectively) were offered $2.5 \mathrm{~kg}$ DM kale $/ 100$ $\mathrm{kg} \mathrm{LW} /$ day and approximately $3 \mathrm{~kg} \mathrm{DM} /$ heifer/day of either perennial ryegrass or plantain baleage. Urine samples were collected 2-4 times throughout winter, acidified and frozen before $\mathrm{N}$ analysis. Despite similar apparent $\mathrm{N}$-intake, urinary $\mathrm{N}$ concentration from heifers supplemented with plantain baleage $(0.36 \%$ $\mathrm{N})$ was lower $(\mathrm{P}<0.05)$ than those supplemented with perennial ryegrass baleage $(0.53 \% \mathrm{~N})$. Creatinine concentrations in urine and observations of urination frequency suggest some of the decrease in urinary- $\mathrm{N}$ concentration may be due to increases in urine volume when heifers were fed plantain baleage. Liveweight gain $(\mathrm{g} /$ heifer/day) was similar $(\mathrm{P}>0.05)$ for heifers fed either supplement. The results indicate that feeding plantain baleage to dairy heifers grazing kale in winter may be a useful approach to decrease the $\mathrm{N}$ loading in urine patches with subsequent reductions in nitrate leaching.
\end{abstract}

Keywords: dairy heifer, kale, plantain, urinary nitrogen

\section{Introduction}

The environmental impacts of intensive, pasture-based livestock systems has been the subject of increasing amounts of research as regulations on nitrate leaching are developed (Ministry for Environment 2011). Nitrogen (N) from urine patches is a major contributor to $\mathrm{N}$ leaching (Di \& Cameron 2007) due to the high loading of $\mathrm{N}$ in urine patches compared with the capacity of many plants species to absorb N. This is particularly relevant to feeding systems where livestock graze forage crops (e.g., kale or fodder beet) during the winter. The high stocking densities used to harvest the high DM yield crops during the winter can result in large nitrate leaching losses relative to the farms total environmental impact (Monaghan et al. 2007; Malcolm et al. 2015).
Recent work has identified a potential role for more diverse pastures containing the herbs chicory (Cichorium intybus) and plantain (Plantago lanceolata) in reducing nitrate losses relative to standard perennial ryegrass and white clover pasture. Totty et al. (2013) and Woodward et al. (2012) reported lower urinary $\mathrm{N}$ concentration and estimated urinary $\mathrm{N}$ excretion in dairy cows grazing diverse rather than standard pastures. Although the mechanisms of such effects were unclear, it is possible that this effect could be associated with one or more specific components of these pastures rather than the diversity of pastures itself (Pembleton et al. 2015). Plantain has biologically active secondary plant compounds (Stewart 1996) including aucubin, catapol and verbascoside, which may cause diuretic effects (O'Connell et al. 2016). Box et al. (2016) reported lower urinary $\mathrm{N}$ concentration and excretion in dairy cows grazing a pasture made up of $50 \%$ pure plantain and a $50 \%$ perennial ryegrass-white clover mixture by area than a perennial ryegrass-white clover mixture. However, no studies have been conducted with plantain in winter-feeding systems, and it is unclear whether the plantain effect can be delivered with conserved rather than fresh forage.

The aim of this study was to compare the urinary $\mathrm{N}$ concentration of dairy heifers in winter on a kale diet supplemented with either plantain or perennial ryegrass baleage.

\section{Methods}

\section{Experimental site, design and crop management}

The experiment was carried out over 2 years on kale grown as a winter forage at Agricom's Marshdale trial site near Oxford, Canterbury. The trial was conducted with the approval of the Lincoln University Animal Ethics Committee (AEC 524). In Year 1, 90 Friesian $\mathrm{x}$ Jersey dairy heifers (180 kg liveweight (LW), age 8 months) from a commercial dairy herd were used for the experiment. The heifers were blocked on LW into 6 groups of 15 animals and groups were allocated to three replicates of two treatment groups: heifers fed kale (Brassica oleracea) with ryegrass (Lolium perenne) or plantain (Plantago lanceolata) baleage. In Year 2, 80 heifers from the same source were randomly allocated 
to two groups of 40 heifers and groups allocated to two treatment groups: heifers fed kale with ryegrass or plantain baleage.

Heifers were grazed on kale ( $c v$. Sovereign) for 56 days between 21 June and 16 August 2013 in Year 1, and between 20 June and 15 August 2014 in Year 2. The feeding treatments were $2.5 \mathrm{~kg} \mathrm{DM}$ kale/100kg LW/day and $3 \mathrm{~kg} \mathrm{DM} /$ heifer/day of either ryegrass or plantain baleage. Lines of baleage were selected to contain similar amounts of N/kg DM. The heifers were allocated their baleage and kale together at 9 am and were offered a fresh break of kale every day with their allocated area determined by weekly measurements of crop DM yield and fortnightly LW measurements. Heifers were adapted to crops over the 7 days of Week 1 .

\section{Animal and plant measurements}

Throughout the 8 weeks of grazing, measurements were made of pre- and post-grazing forage mass of kale from which DM utilisation and apparent DM intake were calculated. Spot samples of urine and faeces were collected on one day in weeks 3 and 8 of the trial in Year 1 and one day in weeks 2, 4, 6 and 8 in Year 2. Samples were collected from all 90 (Year 1) or 80 heifers (Year 2) between $11 \mathrm{am}$ and $1 \mathrm{pm}$. Urine was collected midstream after stimulation by rubbing the vulva by hand, and acidified with sulphuric acid. Faecal samples were collected by manually stimulating defecation. Urine and faeces analyses were performed by Lincoln University Analytical Services (Lincoln University, Christchurch, New Zealand). Faecal and urine samples were stored frozen $\left(-20^{\circ} \mathrm{C}\right)$. Faecal samples were thawed and subsampled; one subsample was weighed and then oven-dried at $65^{\circ} \mathrm{C}$ for $48 \mathrm{~h}$ and re-weighed to ascertain DM and another was freeze-dried, ground to 1 $\mathrm{mm}$, and analysed for percentage of $\mathrm{N}$. Urine and faecal $\mathrm{N}$ percentages were determined using a $\mathrm{N}$ analyser (Vario MAX CN, Elementar Analysensysteme, Hanau, Germany). Creatinine concentration of urine was determined by the Jaffe method (Bartels \& Bohmer 1971; Cobas Mira Plus Analyser, Roche Hitachi, Basel, Switzerland). Heifer LW was recorded in the morning, directly off pasture at the start of the experiment and fortnightly thereafter. Average daily LW gain was determined by linear regression of LW on days. In Year 2 , the number of urination events in each group during 1 hour was recorded on 1 day of each week. Observers stationed in each paddock recorded, concurrently, urination events for 1 hour around midday. Samples of kale and baleage were taken during each week urine and faecal samples were collected. Herbage samples were freeze-dried, ground to $1 \mathrm{~mm}$, and scanned by near infra-red spectrophotometry (NIRS, NIRSystems 5000, Foss, Maryland, USA) to predict ME and N.

The effect of supplement type on $\mathrm{N}$ intake and urinary $\mathrm{N}$ concentration was analysed by repeated measures ANOVA. In Year 1, the experimental unit was the average of each replicate group of heifers $(n=3 /$ treatment group). In Year 2, when there were only two groups, the experimental unit was the heifer $(n=40 /$ treatment group). The number of urinations in 1 hour was analysed by ANOVA with sampling date as the replicate.

\section{Results}

The pre-grazing yield, $\mathrm{N} \%$ and $\mathrm{ME}$ of kale averaged $9900 \mathrm{~kg} \mathrm{DM} / \mathrm{ha}, 2.9 \% \mathrm{~N}$, and $13.0 \mathrm{MJ} \mathrm{ME} / \mathrm{kg} \mathrm{DM}$ in Year 1 and $9600 \mathrm{~kg} \mathrm{DM} / \mathrm{ha}, 2.9 \% \mathrm{~N}$, and $13.4 \mathrm{MJ}$

Table 1 Mean apparent nitrogen (N) intake, and urinary $\mathrm{N}$ and creatinine for dairy heifers fed kale supplemented with perennial ryegrass or plantain baleage over 2 years. LSD = least significant difference $(a=0.05)$ for comparison of supplements within each sampling date.

\begin{tabular}{|c|c|c|c|}
\hline $\begin{array}{l}\text { Appar } \\
\text { (g N/r }\end{array}$ & $\begin{array}{l}\text { ent } N \text { intake } \\
\text { heifer /day) }\end{array}$ & $\begin{array}{l}\text { Urinary-N } \\
(\%)\end{array}$ & $\begin{array}{c}\text { Creatinine } \\
(\mathrm{mmol} / \mathrm{l})\end{array}$ \\
\hline \multicolumn{4}{|l|}{ Year 1} \\
\hline \multicolumn{4}{|l|}{12 July } \\
\hline Ryegrass & 191 & 0.41 & 2.27 \\
\hline Plantain & 197 & 0.48 & 2.72 \\
\hline \multicolumn{4}{|l|}{16 Aug } \\
\hline Ryegrass & 202 & 0.44 & 2.49 \\
\hline Plantain & 226 & 0.24 & 1.38 \\
\hline \multicolumn{4}{|l|}{$P$ value } \\
\hline Supplement & & 0.36 & 0.31 \\
\hline Date & & 0.12 & 0.08 \\
\hline Supplement $x$ date & & 0.04 & 0.04 \\
\hline LSD & & 0.18 & 0.97 \\
\hline \multicolumn{4}{|l|}{ Year 2} \\
\hline \multicolumn{4}{|l|}{4 July } \\
\hline Ryegrass & 158 & 0.45 & 3.3 \\
\hline Plantain & 158 & 0.31 & 3.1 \\
\hline \multicolumn{4}{|l|}{18 July } \\
\hline Ryegrass & 155 & 0.59 & 4.1 \\
\hline Plantain & 165 & 0.25 & 2.1 \\
\hline \multicolumn{4}{|l|}{1 Aug } \\
\hline Ryegrass & 169 & 0.76 & 5.6 \\
\hline Plantain & 194 & 0.51 & 4.4 \\
\hline \multicolumn{4}{|l|}{15 Aug } \\
\hline Ryegrass & 207 & 0.52 & 3.7 \\
\hline Plantain & 199 & 0.37 & 4.2 \\
\hline \multicolumn{4}{|l|}{$P$ value } \\
\hline Supplement & & $<0.01$ & $<0.01$ \\
\hline Date & & $<0.01$ & $<0.01$ \\
\hline Supplement $\mathrm{x}$ date & & $<0.01$ & $<0.01$ \\
\hline LSD & & 0.08 & 0.39 \\
\hline
\end{tabular}


$\mathrm{ME} / \mathrm{kg} \mathrm{DM}$ in Year 2 respectively. The N\% and ME of plantain baleage averaged $2.3 \% \mathrm{~N}$ and $10.1 \mathrm{MJ} \mathrm{ME} /$ $\mathrm{kg} \mathrm{DM}$ in Year 1, and $2.5 \% \mathrm{~N}$ and $10.0 \mathrm{MJ} \mathrm{ME} / \mathrm{kg} \mathrm{DM}$ in Year 2. These values were similar to those found in the perennial ryegrass baleage in Year $1(1.9 \% \mathrm{~N}$ and 11.0 MJ ME/kg DM) and Year $2(1.9 \% \mathrm{~N}$, and $11.0 \mathrm{MJ}$ $\mathrm{ME} / \mathrm{kg} \mathrm{DM})$. Apparent $\mathrm{N}$ intake, calculated from DM utilisation and $\mathrm{N}$ composition of kale and supplement was similar $(\mathrm{P}>0.05)$ between plantain and ryegrass supplement (Table 1).

LW gain of calves was similar $(\mathrm{P}>0.05)$ between supplements in Year 1 (plantain, $964 \mathrm{~g} /$ day; ryegrass $993 \mathrm{~g} /$ day) and Year 2 (plantain, $676 \mathrm{~g}$ /day; ryegrass $669 \mathrm{~g}$ /day). Urinary $\mathrm{N}$ concentration was lower $(\mathrm{P}<0.05)$ for heifers fed plantain than ryegrass baleage at all sampling dates over the 2 years of trial except 12 July in Year 1 (Table 1). The concentration of urine creatinine followed a similar pattern to urine $\mathrm{N}$ concentration (Table 1). In the one hour observation periods, there were more $(\mathrm{P}<0.01)$ urination events for heifers fed plantain (53 urinations/40 cows) than ryegrass (29 urinations $/ 40$ cows) baleage ( $\mathrm{SED}=$ 6.0 ). There was no significant difference in faecal $\mathrm{N}$ concentration between cows fed plantain $(2.3 \% \mathrm{~N})$ or ryegrass $(2.1 \% \mathrm{~N})$ baleage.

\section{Discussion}

The reduction in urinary $\mathrm{N}$ concentration when plantain baleage was fed to dairy heifers potentially offers a useful management tool for farmers wishing to reduce $\mathrm{N}$ loading on winter forage crops. Supplementing dairy heifers with plantain rather than perennial ryegrass baleage resulted in a markedly lower urinary $\mathrm{N}$ concentration while delivering similar LW gain. This effect was evident despite baleage only making up a small proportion (approximately 0.30 ) of the diet. The reduced urinary $\mathrm{N}$ concentration when plantain baleage was fed is consistent with previous studies noting lower urinary concentration when plantain is fed as a fresh forage to dairy cows (Totty et al. 2013; Box et al. 2016). Given that the reduction in urinary $\mathrm{N}$ concentration reported here is comparable to those reported for diverse pasture experiments (Totty et al. 2013) in which plantain was a component, it is suggested that much of this previously reported effect is a plantain effect, rather than one created by diet diversity per se.

The reason for the lower urinary $\mathrm{N}$ concentration is unclear. Previous studies have consistently shown the excretion of $\mathrm{N}$ in urine to be linearly related to $\mathrm{N}$ intake (Tas et al. 2006). However, in this experiment the difference in apparent $\mathrm{N}$ intake between heifers fed ryegrass and plantain baleage was small at $11 \mathrm{~g} \mathrm{~N} / \mathrm{cow} /$ day (and numerically higher for plantain) and is therefore unlikely to explain the large $(1.7 \mathrm{~g} \mathrm{~N} / \mathrm{L})$ difference in urinary $\mathrm{N}$ concentration. There was no difference in faecal nitrogen suggesting this was not a route of increased excretion. Greater urine volume from heifers grazing plantain is a potential explanation for the lower urinary $\mathrm{N}$ concentration. In this study, more frequent urinations were recorded in cows fed plantain baleage, when observed for short periods during the day, and lower urine creatinine concentrations in heifers offered plantain baleage would be consistent with increased urine volumes. Urine volume may be increased by consuming diets with higher mineral content (Ledgard et al. 2015), secondary plant compounds that induce diuresis, or consumption of feeds low in DM. In this study, both water and organic matter content of the diet were similar between treatments, although plantain has been suspected to have diuretic properties (Stewart 1996), but not detected in the closely related species Plantago major (Doan et al. 1992). However, recent data (O'Connell et al. 2016) strongly supports a sustained diuretic activity in a specific line of narrow leaf plantain (Plantago lanceolata).

\section{Conclusions}

This field study provides evidence that diets containing approximately $30 \%$ plantain baleage reduce urinary $\mathrm{N}$ concentration, possibly through increased urine volume. The decline in urine $\mathrm{N}$ concentration observed may decrease urine patch $\mathrm{N}$ loading, thereby reducing the risk of nitrate leaching from dairy grazing systems. Importantly, the effect on urinary $\mathrm{N}$ observed here was delivered in a conserved rather than fresh forage, increasing the flexibility of feeding plantain as a mitigation strategy.

\section{ACKNOWLEDGEMENTS}

The authors thanks the technical input from both Kimihia Research and Lincoln University staff for sample collection.

\section{REFERENCES}

Bartels, H.; Bohmer, M. 1971. Micro-determination of creatinine. Clinica Chimica Acta 32: 81-85.

Box, L.A.; Edwards, G.R.; Bryant, R.H. 2016. Milk production and urinary nitrogen excretion of dairy cows grazing perennial ryegrass-white clover and pure plantain-pastures. Proceedings of the New Zealand Society of Animal Production 76: 18-21.

Doan, D.D.; Nguyen, N.H.; Doan, H.K.; Nguyen, T.L.; Phan, T.S.; van Dau, N.; Grabe, M.; Johansson, R.; Stjernstrom, H.E. 1992. Studies of the individual and combined diuretic effect of four Vietnamese traditional herbal remedies (Zea mays, Imperata cylindrical, Plantago major and Orthosiphon stamineus). Journal of Ethnopharmacology 36: 225231. 
Di, H.J.; Cameron, K.C. 2007. Nitrate leaching losses and pasture yields as affected by different rates of animal urine nitrogen returns and application of a nitrification inhibitor - a lysimeter study. Nutrient Cycling and Agroecosystems 79: 281-290.

Ledgard, S.F.; Welten, B.; Betteridge, K. 2015. Salt as a mitigation option for decreasing nitrogen leaching losses from grazed pastures. Journal of the Science of Food and Agriculture 95: 3033-3040.

Malcolm, B.J.; Cameron, K.C.; Edwards, G.R.; Di, H.J. 2015. Nitrogen leaching losses from lysimeters containing winter kale: the effects of urinary $\mathrm{N}$ rate and DCD application. New Zealand Journal of Agricultural Research 58: 13-25.

Monaghan, R.M.; Wilcolk, R.J.; Smith, L.C.; Tikkisetty, B.; Thorrold, B.S.; Costal, D. 2007. Linkages between land management activities and water quality in intensively farmed catchment in southern New Zealand. Agriculture, Ecosystems and Environment 118: 211-222.

O'Connell, C.A.; Judson, H.G.; Barrell, G.K. 2016. Sustained diuretic effect of plantain when ingested by sheep. Proceedings of the New Zealand Society of Animal Production 76: 14-17.

Pembleton, K.G.; Tozer, K.N.; Edwards, G.R.; Jacobs, J.L.; Turner, L.R. 2015. Simple versus diverse pastures: Opportunities and challenges in dairy systems. Animal Production Science 55: 893-901.

Stewart, A.V. 1996. Plantain (Plantago lanceolata) - a potential pasture species. Proceedings of the New Zealand Grassland Association 58: 77-86.

Tas, B.M.; Taweel, H.Z.; Smit, H.J.; Elgersma, A.; Dijkstra, J.; Tamminga, S. 2006. Utilisation of N in perennial ryegrass cultivars by stall-fed lactating dairy cows. Livestock Science 100: 159-168.

Totty, V.K.; Greenwood, S.L.; Bryant, R.H.; Edwards, G.R. 2013. Nitrogen partitioning and milk production of dairy cows grazing simple and diverse pastures. Journal of Dairy Science 96: 141-149.

Woodward, S.L.; Waghorn, G.C.; Bryant, M.A.; Benton, A. 2012. Can diverse pasture mixtures reduce nitrogen losses? Proceeding of the 5th Australasian Dairy Science Symposium: 463-464. 